\title{
Neuvostotieteen synty
}

Tänä vuonna tulee kuluneeksi 60 vuotta Lokakuun vallankumouksesta. Koska Lokakuun vallankumous merkitsi tärkeätä virstanpylvästä koko ihmiskunnan historiassa, kokonaan uuden aikakauden alkua, on selvä, ettã hyvin monet asiat tulevat tänä vuonna käsittelyn piiriin. Yhden merkittävän asiakokonaisuuden muodostaa teema Lokakuun vallankumous ja tiede. J. D. Bernal kirjoitti kymmenen vuotta sitten hyvin perustein: "Vuosi 1917 avasi tieteessä lähes yhtä tärkeän aikakauden kuin se avasi politiikan alalla ja siihen läheisesti liittyen." Neuvostotieteen syntyä tunnetaan meillä kovin vähän. Sen pääpiirteiden tunteminen on kuitenkin tärkeää ei suinkaan pelkästään tieteen historian kannalta, vaan ennen kaikkea sen vuoksi, että neuvostotieteen synty mitä selvimmin osoittaa, millainen ylipäänsä on sosialismin suhde tieteeseen, tutkimukseen, tutkijoihin.

Heti Lokakuun vallankumouksen tapahduttua nousi mitä kiireellisimpänä tehtävänä eteen tieteen ja tutkimuksen elvyttäminen, erityisesti suhteiden luominen neuvostovallan sekä vanhimman ja perinteikkäimmän tieteellisen instituution, Venäjän tiedeakatemian välille. Vuoden 1917 lopulla Lenin otti vastaan eräitä akatemian jäseniä ja keskusteli heidän kanssaan tiede-elämän järjestämisestä. Heti ensi viikkoina ja kuukausina Lokakuun jälkeen neuvostohallituksen ja tiedeakatemian välille syntyi vilkas kirjeenvaihto, jossa käsiteltiin akatemian ja uuden vallan välisiä suhteita, akatemian tieteellisen luonteen turvaamista, tutkimusvarojen myöntämistä, työskentelymahdollisuuksien turvaamista, uusien tutkimuslaitosten, laboratorioiden ja museoiden perustamista, kirjastoja sekä kansantalouden elvyttämisen kannalta keskeisten tutkimushankkeiden käynnistämistä. Kirjeenvaihto kasvoi muistioiden vaihdoksi ja se puolestaan konkreettisten suunnitelmien kirjaamiseksi. Helmi-huhtikuussa 1918 organisointityö alkoi jo olla täydessä vauhdissa. Näin sai alkunsa jättiläisurakka neuvostotieteen synnyttämiseksi, akatemian uudistamiseksi - säilyttäen vanhan akatemian parhaat perinteet - sekä aivan uudenlaisen tieteen, tekniikan ja tuotannon yhteyden luomiseksi. Leninin ratkaiseva henkilökohtainen panos tässä työssä on yleisesti tunnettu. Hänen ohellaan kehitystyöhön osallistuivat mm. Lunatsarski ja oma-aloitteisen aktiivisesti Gorki, akatemian puolelta ennen kaikkea orientạlisti Sergei Oldenburg ja geologi Aleksandr Karpinski, kumpikin akateemikkoja jo vanhan akatemian ajoilta.

Kun taantumukselliset voimat neuvostovaltion ulkopuolella levittivät kauhukuvia siitä, että bolshevikkihallitus merkitsee kaiken kulttuurin murskaamista, tapahtui neuvostovaltiossa jotain aivan päinvastaista: tieteen ja tutkimuksen jälleenrakentaminen, elvyttäminen ja vauhdittaminen. Venäjän vanha tiedeakatemia oli 1700- ja 1800-luvuilla ollut yksi maailman merkittävimpiä tieteen keskuksia (Lomonosov, Lobatsevski, Mendelejev), ja sen yhteydessä oli esiintynyt useita demokraattisia ja vallankumouksellisia tendenssejä (mainittakoon, että sellaiset suuret valistusmiehet ja materialistit kuten Diderot, Voltaire, d'Alembert ja Holbach olivat olleet akatemian kunniajäseniä), mutta Lokakuun vallankumousta edeltäneenä ajanjaksona, tsaarin, tilanherrojen ja kapi- 
talistien vallan alaisuudessa akatemia oli heikentynyt. Lokakuun vallankumouksen aikaan akatemian jäsenmäärä oli pieni, sillä oli vain yksi instituutti ja hyvin vähän laboratorioita. Sen paremmin ei ollut yliopistojen eikä tieteellisten seurojen laita. Neuvostovallan tehtäväksi tuli akatemian ja muiden tieteellisten ja tutkimusinstituutioiden kokoaminen sosialistisen rakennustyön tueksi.

Leninin kuuluisan kaavan mukaan kommunismi $=$ neuvostovalta + koko maan sähköistäminen. Sähköistäminen ei ollut tarpeen ainoastaan maan talouden takapajuisuuden voittamiseksi, vaan myös koneellisen suurteollisuuden perustan luomiseksi. Useissa kirjoituksissaan ja puheissaan Lenin korosti sähköistämisen ja suurteollisuuden luomisen välttämättömyyttä, luonnonvarojen kartoittamista ja koulutustason kohottamista sosialismin edellyttämän työn tuottavuuden saavuttamiseksi. Lenin teki selväksi, että vallankumouksen sotilaallisten tehtävien, tasavallan puolustamisen tehtävien tultua suoritetuiksi, nousee päiväjärjestykseen tärkein ja vaikein tehtävă: taloudellinen tehtävä. "Tiedämme, ettei kommunistista yhteiskuntaa voida rakentaa, ellei jälleenrakenneta teollisuutta ja maataloutta, mutta niitä ei saa rakentaa entisenlaisiksi. $\mathrm{Ne}$ on rakennettava uudelleen nykyaikaisen uusimman tieteen pohjalta." Kysymys tieteen ja tutkimuksen edustajien ja eri alojen spesialistien saamisesta mukaan sosialismin rakennustyöhön tulee vallankumouksen jatkamisen elinvälttämättömyydeksi. "Ilman tiedon, tekniikan ja käytännön eri alojen spesialistien johtoa ei voida siirtyä sosialismiin, sillä sosialismi vaatii tietoista, etenevää joukkoliikettä, se vaatii kohottamaan työn tuottavuuden kapitalismin saavutusten perusteella korkeammalle kuin se on kapitalismin aikana. Sosialismin tulee omalla tavallaan, omia menetelmiään käyttäen - sanokaamme konkreettisemmin: neuvostomenetelmiä käyttāen - järjestää tuo etenevä liike."

Uuden akatemian lähtölaukauksena voidaan pitää Leninin "Tieteellisteknisten töiden suunnitelmaluonnosta" huhtikuulta 1918. Lenin kirjoitti: "Tiedeakatemialle, joka on alkanut järjestelmällisesti tutkia ja perehtyä Venäjän luontoperäisiin tuotantovoimiin, on annettava heti Korkeimman kansantalousneuvoston nimessä tehtäväksi mùodostaa spesialisteista useita toimikuntia, joiden tehtävänä on laatia mahdollisimman pian Venäjän teollisuuden uudelleenjärjestelyä ja taloudellista nousua koskeva suunnitelma." Lenin hahmotteli edelleen, mitä tähän suunnitelmaan tuli kuulua, todeten erityisesti teollisuuden järkiperäisen sijoittamisen, tuotannon järkiperäisen yhdistämisen ja keskittämisen, neuvostotasavallan ja sen alueiden mahdollisuuden itsenäisesti turvata raaka-aineiden saanti ja tärkeimpien teollisuudenalojen perustaminen; edelleen hän korosti teollisuuden, liikenteen ja maatalouden sähköistämistä ja muiden energialähteiden käyttöä. Huhtikuussa kansankomissaarien neuvosto antoi päätöksen tiedeakatemian rahoittamisesta. Työ lähti käyntiin, ja se tapahtui mitä vaikeimmissa olosuhteissa, neuvostovallan puolustautuessa koko maailman yhdistyneen imperialismin sotilaallista, taloudellista ja poliittista hyökkäystä vastaan ja kansalaissodan oloissa. 
Hyvin mittaviin toimenpiteisiin ryhdyttiin kansankomissaarien neuvoston päätösten pohjalta:

Akatemian ensimmäinen työ oli maan luonnonvarojen kartoittaminen. Eri raaka-ainevaroista ja niiden hyödyntämisestä laadittiin selvitykset, ja eri kohteita tutkimaan lähetettiin retkikuntia.

Sähköistämissuunnitelma pantiin alulle. Leninin aloitteellisuus ja mielenkiinto GOELRO:n toimintaa kohtaan kesti koko hänen jäljelläolevan elämänsä ajan, aina viimeisiin päiviin saakka. Jo vuoden 1918 alussa, kun uusi valta ei ollut edes vakiintunut, aloitettiin pitkällä tähtäimellä voimalaitosverkoston suunnittelu ja ensimmäisten vesivoimaloiden rakennustyöt.

Pantiin toimeen akatemiauudistus. Akatemiaa laajennettiin, perustettiin uusia instituutteja, rakennettiin kirjastoja, museoita ja laboratorioita. Kokonaan oman lukunsa muodostaa opetus- ja korkeakoululaitoksen laajentaminen ja täydellinen uudistaminen.

Ryhdyttiin tutkimustyön edellytysten turvaamiseen ja parantamiseen. Lenin itse osoitti suurta huolenpitoa akateemikko Pavlovin työskentelymahdollisuuksista. Neuvostovallan vaikeimpina vuosina puutetta oli kaikkialla ja kaikissa muodoissa, puutetta oli paperista, polttopuista, vaatteista, ruuasta. Maksim Gorkin aloitteesta perustettiin komissioita tiedemiesten aseman parantamiseksi.

Kansainvälisiä tieteellisiä kontakteja ryhdyttiin elvyttämään ja monella alalla luomaan kokonaan alusta. Kaksikymmenluvun taitteessa kyettiin luomaan kulttuuriyhteistyötä mm. Saksan tieteen edustajien kanssa; sellaiset suuret tiedemiehet ja demokraatit kuten Albert Einstein ja Max Planck kannattivat oma-aloitteisesti ja aktiivisesti yhteistyötä neuvostotu tkijoiden kanssa.

Tämä luettelo neuvostovallan ja neuvostoakatemian ensimmäisistä yhteisistä toimenpiteistä ei kata tietenkään kaikkea, mutta osoittaa kehityksen pääpiirteet ja pääsuuntaukset. Neuvostohallituksen yksimielisen ja selkeän käsityksen mukaan tieteellä oli keskeinen rooli sosialismin rakennustyössä. Neuvostohallituksen korostama tieteen, tekniikan ja teollisuuden elävän yhteyden luominen ei suinkaan merkinnyt mitään tieteen "alistamista" hallinnollisille määräyksille tai hetkellisille "hyötynäkökohdille"; vallankumouksellisina dialektikkoina bolshevikit olivat aivan hyvin selvillä siitä, että tieteen ja käytännön lähentäminen toisiinsa edellyttää samalla perustutkimuksen merkityksen korostamista ja tieteen arvostamista tie teenä. Lenin korosti tätä jatkuvasti. On välttämätöntä, että tiede ja tutkimus saadaan hyödyttämään proletariaatin etua ja sosialistista rakennustyötä; samanaikaisesti on välttämätöntä, että proletariaatti ja sosialistinen yhteiskunta omaksuvat parhaan kaikesta siitä kasautuneesta tiedosta, jonka ihmiskunta on kehittänyt vuosisatojen kulussa. Tärkeässä puheessaan "Nuorisoliiton tehtävät" lokakuussa 1920 Lenin korosti voimakkaasti, että on kriittisesti omaksuttava ja muokattava kaikki aikaisemmin luotu tieto. "On muistettava tämä, kun puhumme esimerkiksi proletaarisesta kulttuurista. Ellemme käsitä selvästi, että proletaarinen kulttuuri voidaan luoda vain sillä 
pohjalla, että tunnetaan tarkoin koko ihmiskunnan kehityksen luoma kulttuuri, että muokataan se uudestaan, ellemme käsitä sitä, emme voi ratkaista tätä tehtävää. Proletaarinen kulttuuri ei ole hypännyt esiin mistään tuntemattomasta paikasta eivätkä sitä ole keksineet ihmiset, jotka sanovat itseään proletaarisen kulttuurin erikoistuntijoiksi. Kaikki se on silkkaa pötyä. Proletaarisen kulttuurin täytyy olla niiden tietovarojen lainmukaista kehittämistä, joita ihmiskunta on luonut kapitalistisen yhteiskunnan, tilanherrain yhteiskunnan, virkavaltaisen yhteiskunnan sorron alaisuudessa. Kaikki nämä tiet ja polut ovat johdattaneet, johdattavat ja johdattavat vastedeskin proletaariseen kulttuuriin aivan samoin kuin Marxin uudelleen muokkaama kansantaloustiede osoitti meille, mihin ihmisyhteiskunta on kulkeva, osoitti, että on siirrytty luokkataistelun ja alkavan proletaarisen vallankumouksen kauteen."

Lenin ottaa tässä välimatkaa ns. proletkult-liikkeen katsomuksiin, joiden mukaan proletariaatti on heittänyt menemään kaiken aikaisemman tieteen ja kulttuurin ja aloittaa kokonaan alusta. Leniniläinen näkemys on, että proletariaatin täytyy omaksua ja jatkaa ihmiskunnan luoman tieteen ja kulttuurin parhaita perinteitä; ts. kysymys ei ole kaiken luodun kritiikittömästä hylkäämisestä tai kritiikittömästä hyväksymisestä, vaan aivan niin kuin yhteiskunnallinen vallankumous sisältää sekä jatkumattomuuden että jatkuvuuden aineksia, samoin on myös sosialistisen kulttuurivallankumouksen laita. "Proletaarisen kulttuurin täytyy olla niiden tietovarojen lainmukaista kehittämistä, jotka ihmiskunta on luonut", kuuluu Leninin teesi. Lenin moitti sellaisia "fanaattisia kommunisteja", jotka tahtoivat toteuttaa akatemiauudistuksen jonkinlaisena epämääräisenä mullistuksena. Neuvostotieteen akatemia syntyi uutena akatemiana, mutta kiinteässä yhteydessä tieteen ja tieteellisen elämän parhaisiin perinteisiin.

Venäjän vanha tiedeakatemia ei Lokakuun edellä suinkaan ollut sellainen läpikotaisin taantumuksellinen pesäke kuin helposti saattaisi kuvitella. Venäjän tieteen ja yliopistojen piirissä oli esiintynyt selkeitä demokraattisia ja vallankumouksellisia tendenssejä 1905, sitä seuraavana taantumuskautena ja vuoden 1917 kahdessa vallankumouksessa. Bolshevikkipuolueella oli jäseniä ja liittolaisia myös tiedeakatemian piirissä. Silti tiedemiesten enemmistö oli poliittisilta katsomuksiltaan porvarillista tai puolueetonta. Lokakuun vallankumouksen yhteydessä ja sen jälkeen joukko tiedemiehiä poistui maasta, mutta heitä oli selvä vähemmistö. Keskeiseksi tehtäväksi tuli kaikkien tiedemiesten ja tutkijoiden - edustivat he sitten mitä poliittista kantaa tahansa - valloittaminen sosialistiseen rakennustyöhön ja samalla oman tieteellisen työnsä jatkamiseen. Tämän tehtävän suorittamisessa käytettiin mm. aineellisia kannusteita, kuten korkeita palkkoja. Lenin teki tämän välttämättömyyden täysin selväksi joukoille, sitä ei salattu ollenkaan. Oli tietysti sellaisia tiedemiehiä ja spesialisteja, joita kiinnosti lähinnä oma henkilökohtainen etu, mutta kaikki tosiasiat viittaavat siihen, että pääosa tiedemiehiä ei tavoitellut mitään etuoikeuksia, vaan he halusivat saada ennen kaikkea tutkimustyönsä edellytykset turvatuiksi tyytyen 
usein kaikkein vähimpään. Lenin totesikin, että tiedemiesten ja spesialistien valloittamisessa proletariaatin ja neuvostovallan puolelle ovat moraaliset keinot vähintään yhtä tärkeitä kuin aineellisetkin. Kun tiedemies näkee, miten uusi valta arvostaa hänen työtään, kun insinööri näkee joukkojen innon toteuttaa suunnitelmia, kun lääkäri näkee joukkojen itsensä nousevan taisteluun kulkutauteja vastaan, kun tieteen ja kulttuurin edustajat näkevät, että työväenluokka ja neuvostovalta antavat koulutukselle suuremman merkityksen kuin yksikään aikaisempi historiassa esiintynyt voima - kun kaikki tämä tapahtuu yhä uudestaan ja uudestaan, vakuuttuvat tiedemiehet ja spesialistit oman $\mathrm{k}$ o k e m u k e n s a $\mathrm{k}$ a $\mathrm{t}$ a uuden yhteiskunnan paremmuudesta. Neuvostovallan vielä taistellessa olemassaolostaan kyettiin muutaman vuoden kuluessa taloudellis-sosiaalisin, poliittisin ja moraalisin keinoin synnyttämään jotain aivan uutta inhimillisen tieteen historiassa: "uusi tieteellinen sivilisaatio", lainataksemme Bernalin sattuvaa nimitystä.

Tällainen on neuvostotieteen synty. Alkuvuosien jälkeen, uuden tieteellisen sivilisaation synnyn jälkeen, oli vuorossa kasvu. Luonnonvarojen kartoittamisen, sähköistyssuunnitelman ja monien muiden suurten hankkeiden yhteydessä alkoi tapahtua nopea kehitys fysiikassa, geologiassa, metallurgiassa, matematiikassa, vähän myöhemmin kemiassa ja biologiassa ja monilla muilla tieteenaloilla. Toisen maailmansodan jälkeen ja tieteellis-teknisen kumouksen lähdettyä käyntiin on neuvostotieteen kuva entisestään muuttunut, ei ainoastaan määrällisesti, vaan myös laadullisesti. Tänä päivänä Neuvostoliitolla on kokonainen tiedemiesten miljoona-armeija, ja useilla tieteen ja teknisen tutkimuksen aloilla neuvostotiede edustaa maailman kärkeä. Nämä kaikki ovat kuitenkin aivan liian laajoja asioita käsiteltäväksi tässä.

Neuvostotieteen synnyn tutkiminen osoittaa perusteellisesti vääriksi ne monet ennakkoluulot, joita meillä vieläkin niin usein tapaa, milloin tahallisen pahansuovassa, milloin vilpittömän tietämättömässä tarkoituksessa lausuttuja. Sosialismi ei merkitse tieteen "alistamista" politiikalle, ei liioin tiedemiesten muodostumista "etuoikeutetuksi luokaksi". Sosialismi merkitsee ennen kaikkea tieteen ja tutkimuksen esteetöntä kehittymistä ja kasvuedellytysten jatkuvaa turvaamista. Se ei ole sattuma eikä mikään juoni, vaan se on kehityksen kulkuun perustuva, lainmukainen seikka.

Katteetonta puhetta? Tyhjää propagandaa? Ei suinkaan. Sopii katsoa ympärilleen ja verrata, mitkä ovat tutkimuksen kasvuedellytykset ja tutkijan aseman kehityspiirteet kapitalistisissa maissa ja toisaalta Neuvostoliitossa ja muissa sosialistisissa maissa. Lenin sanoi lähes 60 vuotta sitten oikeutetulla ylpeydellä: "Olen vakuuttunut siitä, ettei missään maailmassa arvosteta tiedemiehiä niin kuin meidän sosialistisessa valtiossamme." Silloin se oli rohkea julistus, tänä päivänä se on käsinkosketeltavaa todellisuutta, joka ei voi olla tunkeutumatta yhä useampien tieteen ja tutkimuksen edustajien tietoisuuteen. 


\section{Tässä numerossa}

Lokakuun vallankumouksen 60-vuotisjuhla on myös leninismin juhlaa. Seppo Toiviainen pyrkii artikkelissaan "Leninismi metodina" hahmottelemaan leninismiä politiikan tieteenä. Toiviainen rajoittuu artikkelissaan lähinnä tutkimaan, mitä Lenin tarkoitti edellyttäessään dialektiikan soveltamista politiikkaan.

Tässä numerossa julkaisemme kolme artikkelia luonnontieteiden alalta. Niiden yhteisenä teemana on evoluutioteoria. Evoluutioteorian merkitys ja sen kehittämisessä saavutetut tulokset eivät tietenkään rajoitu yksinomaan luonnontieteen piiriin, vaan niillä on merkitystä myös yhteiskuntatieteen, filosofian ja maailmankatsomuksen kannalta. Olli Järvinen kirjoittaa biologisesta evoluutiosta, Matti Saraste elämän synnyn kemiasta, Seppo Ku usela ja Esa Ranta ihmisen syntyhistorian tutkimuksen tuloksista.

Vuodenvaihteessa ilmestyi Seppo Hentilän ym. laaja tutkimus "Suomen työväenliikkeen historia". Tätä kirjaa on arvioitu useissa lehdissä, useimmiten kuitenkin kovin pinnallisesti, teoksen pääkysymyksiä ja kriittisiä kohtia kiertäen. Kari Toikka ja Matti Viikari ovat kirjoittaneet arvion "Suomen työväenliikkeen historiasta". Tässä numerossa julkaisemme sen ensimmäisen, teoreettis-metodologisen osan. Toivomme, ettei keskustelu päättyisi tähän, vaan että keskustelu kirjan käsittelemistä tärkeistä kysymyksistä todella alkaisi nyt.

Presidentti Carterin neutronipommikampanja on herättänyt laajaa huolta ja suuttumusta. Julkaisemme edustavan joukon tutkijoiden lausuntoja pommista. Ulkomaisia lausuntoja edustaa WFSW:n puheenjohtaja, prof. Eric B u rh o p. Suomalaisista tiedemiehistä ovat lausunnon meille antaneet tieteen keskustoimikunnan puheenjohtaja Helge G y 11 e n b e r g, Tampereen rauhanja konfliktintutkimuslaitoksen johtaja dos. Raimo $V$ ä y $r$ y n e n ja prof. Göran von B o n s d o r f f. Samaan teemaan liittyen julkaisemme Bruno B ä rs i n ja Jorma $L$ i n d f o r s i n artikkelin, joka käsittelee neutronipommin tekniikkaa ja taktiikkaa, sen biologisia vaikutuksia ja merkitystä asevarustelun kannalta.

Yksi maailman tunnetuimpia tutkijajärjestöjä ja tutkijaliikkeitä on Pugwash, mm. Russellin ja Einsteinin aloitteesta 1957 perustettu sodanvastainen liike. Helsingin yliopiston radiokemian laitoksen esimies, prof. Jorma $\mathbf{K}$. Miettinen kirjoittaa elokuussa Münchenissä pidetystä liikkeen 20vuotisjuhlaistunnosta. Prof. Miettinen on Pugwashin kansainvälisen johtokunnan jäsen ja Suomen Pugwash-toimikunnan puheenjohtaja. Edelleen, Raimo Lovio on laatinut artikkelin Pugwash-liikkeen synnystā ja vaiheista.

Puhutun, kohutun ja jopa vihatun Tandem-projektin loppuraportti on valmistunut 600-sivuisena kirjana. Julkaisemme kolme arviota "Demokratian rajoista ja rakenteista". Pekka $S$ u 1 k u n e n arvioi teoksen kokonaiskuvaa, Jan Otto Andersson sen talousanalyysia ja Per S chybergson tuo mukaan historiantutkimuksen näkökulman. Kuten näkyy, kirjoitukset ovat paikoin varsin kriittisiä, samalla kun niissä tunnustetaan Tandemin tutkimuksen kiistaton yhteiskuntatieteellinen ja yhteiskuntapoliittinen merkitys. 